\title{
Collaboration in Implementation of Kota Tanpa Kumuh (KOTAKU) Program in Palangka Raya City
}

\author{
Farid Zaky Yopiannor ${ }^{1}$, Novianto Eko Wibowo ${ }^{2}$ \\ ${ }^{1}$ Departement of Public Administration, Faculty of Social and Political Sciences, Universitas Muhammadiyah \\ Palangkaraya (email: faridzakyump@gmail.com), ${ }^{2}$ Departement of Public Administration, Faculty of Social and \\ Political Sciences, Universitas Muhammadiyah Palangkaraya (email: putararahputarhaluan@gmail.com)
}

\begin{abstract}
The goal number 11 of the 2030 global Sustainable Development Goals (SDG's) agreement is to make the settlement of an inclusive, safe, resilient and sustainable city. The Public Works and Housing Ministry has held a program to improve the quality of urban services and community-based infrastructure, namely the Kota Tanpa Kumuh (KOTAKU). This program has become one of the priorities of the Palangka Raya City since 2016. The purpose of this study was (1) to analyze the implementation performance of the KOTAKU strategic program in Palangka Raya City; (2) to carry out an analysis of the collaborative process between actors in the KOTAKU program. This research is descriptive qualitative research, where data is obtained through observation, interviews and documentation. The study results show that the performance implementatiton of KOTAKU in Palangka Raya was successful. This can be seen from the total slum area which has been reduced significantly. The dynamics of collaboration show that the interactive cycle between principle engagement, shared motivation and capacity for joint action is going well. The CGR performance is supported by two factors, i.e: political dynamic or power relation and initiating leadership.
\end{abstract}

\section{Keywords:}

KOTAKU; collaborative governance; Palangka Raya City

\section{Introduction}

Urban slums become one of the main issues in the framework of sustainable urban development. The goal number 11 of the 2030 global Sustainable Development Goals (SDG's) agreement is to make the settlement of an inclusive, safe, resilient and sustainable city. UN Habitat for Humanity reportes more than 1,6 miliar billion people in the world live without adequate shelter. 1 in every 4 people will live in a slum by 2030, according to current estimates.

Slums are often defined by unsafe homes; Overcrowded homes; Limited or no access to basic services: water, toilets, electricity, transportation. The study in Dhaka (Bangladesh) 
found that most of the people are living in a temporary habitat in vulnerable condition due to low income, lack of support and insecure tenure system (Sinthia, 2013).

In line with Corburn \& Sverdlik (2017), his research about slum upgrading evaluations from cities across Asia, Afrika and Latin America and found that few captured the multiple health benefits of upgrading. There is also a study of slums in Indonesia. According to Alzamil (2018), his research founds that upgrading these settlements in urban slum must be in accordance with a comprehensive plan that includes priority improvements.

In the era of regional autonomy the performance of city government is important to highlight. Now the mayors have a great responsibility to overcome global problems, including urban slums. There are two underlying reasons: (a) More than half the world's people now live in cities and will be an social, economic and cultural engine; (b) the mayor has no burden with the issue of national border sovereignty so that it is easy for them to collaborate with other mayors (Barber, 2013).

Barber's argument is relevant to the achievement of goals contained in SDGs 2030, that is sustainable urban development. Now, the City Government with all its limitations is demanded to collaborate with other stakeholders in accelerating development. There have been many studies from various scientific backgrounds and they draw the conclusion that the concept of collaboration is very relevant to the achievement of SDGs 2030 (Florini \& Pauli, 2018; Mah \& Hills, 2012; Zhou, 2014).

In 2016 there were still 35,291 hectares of urban slums located in almost all parts of Indonesia. The condition is expected to expand if there is no form of treatment that is innovative, comprehensive, and right on target.

As one of the steps to realize these targets The Public Works and Housing Ministry initiated a collaborative platform development program through the City without Slums Program (Kota Tanpa Kumuh/KOTAKU).

In general, this program is an effort to improve the quality of urban services and community-based infrastructure. This program is a national collaborative platform financed by multiple sources, including central and local governments, the private sector, communities, as well as multi-lateral donors with popular tagline "Program 100-0-100", i.e 
100 percent access to potable water, 0 slums, and 100 percent access to sanitation. KOTAKU aims to establish an integrated and collaborative system for slum upgrading interventions.

There have been many studies about KOTAKU. Implementation the KOTAKU program in Kendari was influenced by four factors which included Communication, Disposition, Resources, and Bureaucratic Structure. (Bathari, Solo Limba, \& Mustafa, 2018). Meanwhile the research also takes the topic of KOTAKU, which is analyzed from the perspective of policy communication. The key to the success of this program is the Collaboration process in the form of communication intensity between actors (Yusnadi, Lubis, \& Nuraflah, 2019).

Palangka Raya City is one city that is committed to the success of the KOTAKU program. This program is a priority of Palangka Raya, which has been programmed from 2016 and still running. Slum treatment is based on priority locations covering 105.20 hectares based on the Mayor Decree of Palangka Raya Number 188.45/130/2016 February 1, 2016. Settlements that are categorized as slums can be seen in further detail in the following table.

Tabel 1.

Location of the KOTAKU Program in the City of Palangka Raya

\begin{tabular}{|c|l|l|c|}
\hline \multirow{2}{*}{ No. } & \multicolumn{2}{|c|}{ Lokasi } & Luas Wilayah Kumuh (Ha) \\
\cline { 2 - 3 } & Kelurahan & Kecamatan & \\
\hline 1. & Pahandut & Pahandut & 39,48 \\
\hline 2. & Palangka & Jekan Raya & 9,74 \\
\hline 3. & Langkai & Pahandut & 8,97 \\
\hline 4. & Pahandut Seberang & Pahandut & 16,46 \\
\hline 5. & Kereng Bangkirai & Sebangau & 10,62 \\
\hline 6. & Tangkiling & Bukit Batu & 5,94 \\
\hline 7. & Tumbang Rungan & Pahandut & 4,66 \\
\hline 8. & Menteng TOTAL LUAS & Jekan Raya & 9,33 \\
\hline \multicolumn{2}{|c|}{ Ton } \\
\hline
\end{tabular}

Sumber: Mayor Decree of Palangka Raya Number 188.45/130/2016

Based on the table above, there are eight urban village in the city of Palangka Raya which are categorized as slums. This data is based on the results of the identification and assessment of locations for slum conditions according to $7+1$ indicator criteria, i.e: building; road environment; provision of drinking water; environmental drainage; waste water management; solid waste management; fire protection; and green open space (RTH).

The implementation of the KOTAKU program in Palangka Raya City focuses on accelerating slum management through improving the quality, management and prevention 
of new slums. Technically this program is realized by activities in the City and Urban Village area entities that are the target of the program. This research focuses on the typical platform of the KOTAKU program, that is collaboration. The experts agree that the City Government in the context of development has limitations so that it requires collaboration with other actors and sectors outside the government such as private actors, NGOs and the community. Therefore, this research is important and relevant to be analyzed with the concept of collaborative governance.

There have been many recent studies that have raised collaborative governance but in a varied spectrum of cases. A few examples are studies of collaborative governance with variance in the social and political field (Sabaruddin \& Said, 2018), the field of food policy (Koski, Siddiki, Sadiq, \& Carboni, 2018), administrative culture (Lahat \& Sher-Hadar, 2019), and pubic sector reform (Noh \& Yashaiya, 2018).

Based on the explanantions in the above, the objective of this research is to describe how the implementation performance of KOTAKU and the dynamics of actor collaboration in the implementation of the KOTAKU program in Palangkaraya City.

\section{The Concept of Collaboration}

In a simple way collaboration is interpreted as working with others. It means implies actors, such as individuals, groups, community or organisations work together to solve problems. The word 'collaboration' originally came into use in the nineteenth century as industrialisation developed, more complex organisations emerged and the division of labour and tasks increased (O’Flynn \& Wanna, 2008).

Collaboration is a concept that describes the process of facilitating and operating in multi-organizational arrangements to solve problems that cannot be solved or easily solved by single organizations ( $\mathrm{O}^{\prime}$ Leary \& Vij, 2012). Meanwhile, collaborative also means to colabor, to achieve common goals, often working across boundaries and in multi-sector and multi-actor relationships. Collaboration is based on the value of reciprocity and can include the public (Agranoff \& McGuire, 2003).

Collaboration is described as the process by which actors with autonomous authority interact through formal and informal negotiations. Actors also jointly create rules and structures that govern relationships and ways of acting. In fact, it goes a long way towards 
giving decisions on issues that bring them into the necessity of mutual benefit (Thomson \& Perry, 2006).

Collaboration define as "an approach to solving complex problems in which a diverse group of autonomous stakeholders deliberates to build consensus and develop networks for translating consensus to results" (Margerum, 2011). He focused on building consensus, in line with Ansell \& Gash (2007) the goal of collaboration is typically to achieve some degree of consensus among stakeholders. We use the term consensus oriented because collaborative forums often do not succeed in reaching consensus.

Based on the explanation above, the researcher concludes that the collaboration trend is growing along with the paradigm shift towards governance, where the main actors of the government must cooperate with other actors outside in responding to public problems. Collaboration is a collaborative activity between actors and sectors in solving a public problem. The collaboration is based on shared vision, mission and goals with a foundation of commitment, mutual consensus and the principle of mutual benefit.

Recently, the concept of collaboration became a popular concept used by experts in dissecting the dynamics of public administration. Experts in several of their publications agreed to call the concept of collaboration as Collaborative Governance (Ansell \& Gash, 2007; Donahue, Zeckhauser, \& Breyer, 2011; K. Emerson, Nabatchi, \& Balogh, 2012; Thomson \& Perry, 2006). These experts also developed the concept of collaborative governance into a conceptual framework model that was used as a tool for analysis on various scientific topics.

\section{The Collaborative Governance Model}

Governance is an increasingly popular pillar in the development of contemporary public administration paradigms. The increasingly complex dynamics of development become a challenge for the government as the main actor of development. The Governance paradigm arises in line with the awareness that government capabilities are increasingly limited and thus require the delegation of development tasks to non-governmental actors (private, NGOs, communities).

This concept emphasizes the management of the government involved in having a synergistic and collaborative relationship between the actors (government, private and 
community). Governance is the paradigm of contemporary public administration adopted by most countries in the world, such as Good Governance (Keping, 2018), Dynamic Governance (Neo \& Chen, 2007), and Collaborative Governance (Ansell \& Gash, 2007; K. Emerson et al., 2012; Thomson \& Perry, 2006) .

According Ansell \& Gash (2007) Collaborative governance is a governing arrangement where one or more public agencies directly engage non-state stakeholders in a collective decision-making process that is formal, consensus-oriented, and deliberative and that aims to make or implement public policy or manage public programs or assets.

Collaborative governance is thus an umbrella term that encompasses various interweaving strands of public administration scholarship including intergovernmental and interagency collaboration, regionalism, cross-sector partnerships, public service networks (or simply network studies), consensus building, and public engagement (Morse \& Stephens, 2012).

Meanwhile Emerson, Nabatchi, \& Balogh (2012) stated that the definition of "collaborative governance is the processes and structures of public policy decision making and management that engage people constructively across the boundaries of public agencies, levels of government, and/or the public, private and civic spheres in order to carry out a public purpose that could not otherwise be accomplished."

In collaborative governance, cross-sector of stakeholders from the public, private, and nonprofit sectors are convened for one or more public purposes, including policy making, policy implementation, or coordinating public service delivery tasks (K. Emerson et al., 2012).

Researchers place emphasis on a comprehensive understanding of collaborative governance developed by Kirk Emerson \& Nabatchi (2015). There are five key approaches in understanding the concept of collaborative governance: (1) Collaborative as Institutional Arrangements. From this point of view the experts agree that for multiple organizations to collaborate across boundaries, they must establish, enforce new rules of engagement, develop informal norms and build trust, and create joint strategies for action.

(2) Collaborative Governance as Structural Relations. In this relation perspective, the collaborative process emphasizes interaction patterns. The collaboration process is seen as an interrelated process between actors and organizations both formally and informally. 
(3) Collaborative governance as an Advocacy Coalition. This perspective explains that in the dynamics of policy implementation there are often conflicting subsystems.

(4) Collaborative Governance as an Developmental Process. The essence of this approach is a process whereby parties move from competitive zero-sum bargaining to more cooperative negotiations that optimize mutual gains and minimize aggregate losses.

(5) Collaborative Governance as a Functional Performance Sequence. In this perspective, experts get inspiration from collaborative governance which they consider to be a tool to improve the functional performance of an organization. They also enumerate several preferred outcomes, such as goal achievement, social capital formation, leveraging of new resources, and a capacity for self-governance.

Kirk Emerson \& Nabatchi (2015) developed an integrative framework of collaborative governance in the form of three tiers of interlocking circles, represent System Context, Drivers, The CGR, Collaboration dynamics and actions, outcomes and adoption. This developed model is seen as a concept that explains collaborative governance comprehensively. The model collaborative governance by Kirk Emerson \& Nabatchi (2015) in Figure 1 below:

Figure 1.

Integrative Framework for Collaborative Governance

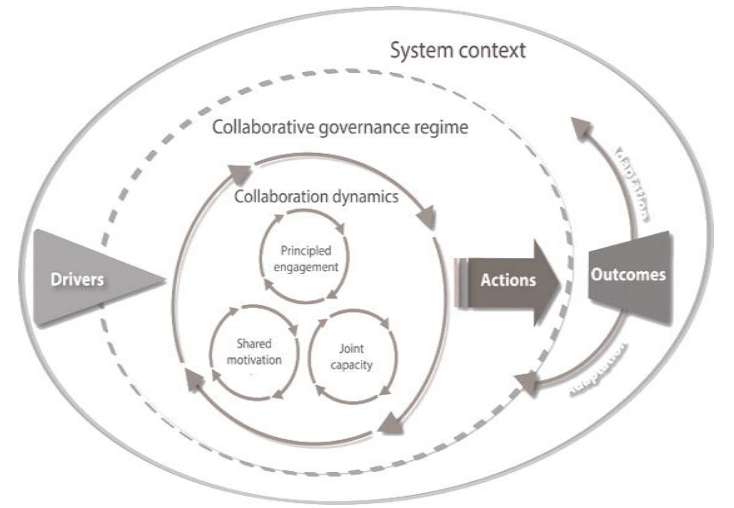

Source: Kirk Emerson and Nabatchi, 2015

Kirk Emerson \& Nabatchi (2015) uses the phrase 'regime' in the model he developed to provide a holistic picture of governance, in other words the phrase 'regime' can be interpreted as a large scope that is an umbrella of all components of the dynamics of collaboration. Based on figure 1 above this integrative model consists of several dimensions that form a cycle: 


\section{The System Context and Drivers}

Collaborative governance is not in a vacuum, but is within the scope of a large system such as political, legal, social, economic and environmental. The context of this system resides in a three-dimensional space and is external and can have an influence on the course of collaborative dynamics; These drivers help to start the CGR, including perceived uncertainty, interdependence, consequential incentives and initiating leadership. Uncertainty refers to situations of doubt, ambiguity, limited information, and instability related to current and future conditions, events, resource availability, or decisions by other actors (Kirk Emerson \& Nabatchi, 2015).

\section{The Collaboration Dynamics}

The collaboration dynamics is a collaborative process consisting of three key components, i.e: principal engagement, shared motivation and capacity for joint action. These are interactive and form an iterative cycle in achieving collaboration goals. More specifically, it can be explained as follows. (1) Principled engagement, or the basic process component of collaboration dynamics, encompasses the interaction of discovery, definition, deliberation, and determinations. During principled engagement, the participants in a CGR develop a shared theory of change, which is, in essence, a strategy for accomplishing the collective purpose and target goals of the CGR.

(2) Shared motivation, or the relational component of collaboration dynamics, consists of trust, mutual understanding, internal legitimacy, and shared commitment. (3) Capacity for joint action, or the functional component of collaboration dynamics, consists of procedural and institutional arrangements, leadership, knowledge, and resources. The elements within each component work together to generate that component, and the components themselves work interactively and iteratively to reinforce one another and propel collaborative actions (Kirk Emerson \& Nabatchi, 2015).

\section{Collaborative Actions, Outcomes and Adaptation}

These are the products of the process of collaboration dynamics. The effectiveness of collaborative actions will be achieved if the objectives of the collaboration are formulated explicitly. These actions vary in general such as improving people's economy, infrastructure 
development, improving the quality of public services, community empowerment, etc. Outcomes define as intermediate changes that associated with collaborative actions. It can be varied, whether intended outcomes or unintended outcomes. Intended means 'small-goals' that is positive result, bu the other side unintended means obstacle of collaboration process. From this outcomes arise feedback adapted by collaboration. The ideal adaptation is positive feedback, where all collaboration actors remain in the corridor of collaboration. This means that the importance of collaboration is still a priority scale among actors (Kirk Emerson \& Nabatchi, 2015).

\section{Methods}

This study used the descriptive qualitative approach with the location of study in Palangka Raya City, Central Kalimantan Province. The urgency of location selection is because this city is one of the implementation targets of the KOTAKU program. This study is focused on two urban villages in Palangka Raya City, namely Menteng and Pahandut. This is assumed to be representative to be the object of study.

The selection of key informants in this study uses purposive sampling technique that is, informants who are assumed to know and are directly involved in the implementation of the program. The key informants in this study is the Public Housing and Settlements Office (Dinas Perumahan Rakyat dan Kawasan Permukiman/DISPERKIM), Perbankan (BANK BTN), Regional Management Consultant (Konsultan Manajemen Wilayah/KMW), Working Group on Water and Sanitation Settlement Housing (Kelompok Kerja Perumahan Permukiman Air Minum dan Sanitasi /POKJA PPAS), Community Self-help Organization (Badan Keswadayaan Masyarakat/BKM), City Coordinator Team, Urban Village Facilitator Team.

This study gathered two types of data, which are primary and secondary data. Data collected includes the performance implementation of KOTAKU and the collaborative governance regime of KOTAKU dynamic process. The data collection techniques used were deep interview, observation, and documentation. The collected data were analyzed with interactive qualitative analysis consisting of data reduction, data display, and drawing conclusions. Data were validated by using triangulation technique. 


\section{Result and Discussion}

\section{The Implementation Performance of KOTAKU in Palangka Raya}

Implementation performance in this study was measured by focusing on aspects of the outcome, consists of five indicator: (1) Decreasing area of slums. Based on Mayor Decree of Palangka Raya No. 188.45/130/2016 slum area in the City of Palangka Raya is 105.2 hectares spread over eight urban villages. Throughout the implementation of the KOTAKU the slum area has decreased significantly, leaving 9.48 hectares. The rest of the slum area is focused on Pahandut urban village, while seven other urban villages have reached the target of zero slum areas.

(2) Establishment of a working group on Water and Sanitation Settlement Housing (POKJA PPAS). It is Mayor Decree of Palangka Raya No. 1888.45/84/2019. It is a bridge between relevant stakeholders. PPAS working group members consist of 30 members from various elements who have the main duties related to slum handling.

(3) Integrating plan for reducing slums at Palangka Raya city. The Mayor's Vision is the realization of a 'Advanced, Peaceful and Prosperous City for all'. The slum treatment plan is integrated with one of the Mayor's missions, that realizing the progress of the smart city based environment including infrastructure development, information technology, water and land management, waste management and spatial planning.

(4) Implementation of joint rules as an effort to change the behavior of clean and healthy living through institutional beneficiary and maintainer groups (Kelompok Pemanfaat $\mathcal{E}$ Pemelihara/KPP). This group has operational rules in the form of maintaining infrastructure from voluntary community retribution.

(5) In Palangka Raya City, amounts thirty Community Self-help Organizations (BKM) were formed. Based on the BKM performance assessment in 2019, out of thirty BKM numbers, around $63 \%$ were included in the Mandiri category and around $37 \%$ were in the Mandiri Madani category.

\section{Collaboration Dynamic in implementation of KOTAKU Program}

KOTAKU has been running for 4 years in Palangka Raya City. This program is a mainstreaming collaboration platform in slum management that integrates various resources and funding sources. The dynamics of collaboration in this program require multi- 
actor involvement. This actor is an important factor that determines the success of a collaborative program. Researcher limited this study to two collaborative-based activities namely environmental road and drainage improvement activities in Menteng urban village; environmental and sanitation based activities in Pahandut urban village. The actors in this study are limited to actors who are directly involved in the activity.

\section{The Government Actor}

The government of Palangka Raya City has an important role as 'Captain' in the implementatiom of the KOTAKU. It's a key actor to mobilize other actors in the success of program. The government, which is represented by the Public Housing and Settlements Office (DISPERKIM) Palangka Raya; Working Group on Housing, Settlement, Water and Sanitation (POKJA PPAS); City Coordinator and Urban Village Facilitator.

\section{The Private Actor}

The private sector has a role as a partner in efforts to attract investment, in order to obtain additional sources of funds and resources. The private institutions, which is represented by PT Bank Tabungan Negara (BTN) Branch of Palangka Raya City. The Bank is the main driver to expand the scope of collaboration by encouraging customers, especially housing developers to participate in issuing CSR.

\section{The Public Actor}

The public actors playing a direct role in the KOTAKU program. The Public actor, which is represented by Community Self-help Organization (BKM), Community Self-Help Group (KSM) and Community Self-Help Institution (LKM). This community institution functions as an agent of change that moves other communities to participate in the success of this program.

\section{The Regional Management Consultant (KMW)}

This actor plays a role in controlling, monitoring, evaluating and quality control throughout KOTAKU program activities. the agency is led by a Team Leader, supported by team members with expertise in urban planning, capacity building, social and environmental impact management.

Collaborative governance requires a common principle so that all actors involved can understand each other's roles. This role is manifested in a shared motivation between actors to achieve program goals. The actors involved must also have a great responsibility to 
participate in collaborative activities. This is relevant to what is illustrated that the key factors of the collaboration process can be portrayed through the collaboration dynamics, such as principle engagement, shared motivation and capacity for joint action (Kirk Emerson \& Nabatchi, 2015).

\section{Principle Engagement}

Principle engagement can be interpreted as an intensive process that grows over time. This process grows through dialogue, face-to-face activities, general meetings, relationships between organizations and settings for formal and informal interactions (Kirk Emerson \& Nabatchi, 2015). Furthermore, this process provides broad opportunities between actors with substantive, relational and identity differences to collaborate across actors and sectors.

Entire of KOTAKU actors in Palangka Raya City are intensively involved in this principle engagement process. This principle equalization activity between actors was established during the workshop held by the provincial and city government. This activity invited whole actors involved in the program. Each actor has an equal portion in expressing opinions.

The Government actors conveyed the targets and achievements of slum reduction, supported by data, facts and studies from Regional Management Consultant (KMW). Community actors represented by the Community Self-help Organization (BKM) were also given the opportunity to explain the best practices for handling slums implemented by each urban village.

The workshop pattern was carried out using the Focus Group Discussion (FGD) model so that the atmosphere was run fluid, dynamic and egalitarian. Each actor discussed mutually expressing issues and collaboration strategies. During the FGD, questions were exchanged, the exchange of information and each actor identified differences and similarities in desires. This process is explained by (Kirk Emerson \& Nabatchi, 2015) as discovery. The process of discovery enables participants to reveal and explain their interests, concerns, and values, along with relevant information and its implications.

Workshop activities are also parallel with the dissemination of information through the media (newspaper, television, radio, poster, leaflet etc). The aim is to provide information, then from that information grows a common understanding of the KOTAKU 
program. This is explained by (Kirk Emerson \& Nabatchi, 2015) as definition, where the community gives the same definition that slums are complex so they need collaboration in overcoming them.

During the preparation phase of the program in urban villages regularly hold community meetings (rembuk warga). The actors involved are the city coordinator, urban village facilitator and Community Self-help Organization (BKM). This forum formed a deliberation (musyawarah). Through this forum the actors involved discuss what kind of slum treatment program will be implemented. Communities through Community Self-help Organization (BKM) become key actors because they have a description of the scale of development priorities in their respective regions.

After all actors have the same understanding, a process called determination is developed. Detemination is a set of actions that determine the purpose of collaboration. The strategic agreement that resulted was that all actors realized that slums must be solved together. At this stage the Government of Palangkaraya City made further strategic agendas such as the preparation of procedural activities and the routine agenda of the whole actor's meeting in future.

Based on the explanation above it can be seen that in the City of Palangka Raya the climate of principle engagement has been created through a workshop or multi-stakeholder meeting. At the urban villages level, it is also routinely carried out in a community meeting in order to work together to solve the problem of slums. This is also strengthened by the interactive process between actors through discovery, definition, deliberation and determination in an effort to create a value that is the prevention and improvement of the quality of slums through collaboration.

\section{Shared Motivation}

Shared motivation is strengthening the cycle of actor interaction based on the principle of social capital, consisting of elements of trust, mutual understanding, internal legitimacy and commitment. The process of mutual trust between collaborating actors is built through the process of mobilizing shared principles. Interaction between actors during the process of program preparation, planning and implementation builds the reality of formal and informal interactions. Formal interactions are formed during workshop and discussion with communities (rembuk warga/musyawarah), while informal interactons are 
built up from Whatsapp coordination group that involve all actors and facilitated by the city coordinator of KOTAKU.

This trust is a mechanism that bridging communication between actors, then also the trust that is built forms a bonding among the actors involved. From this trust process, mutual understanding will grow and to provide internal legitimacy and mutual commitment. Mutual understanding is a sense of mutual understanding that makes fellow actors respect each other and the interests of other actors while compilation of differences of opinion occur. Non-formal interaction through whatsapp coordination group is recognized by the actors as the main media that forms a shared understanding group. All differences of opinion can immediately melt with interaction while sharing interesting content in whatsapp coordination group.

Based on the observations of researchers there is a shared motivation building activity is a 'reflection of slums' activity session that was inserted during a cross-stakeholder workshop. This activity aims to build mutual understanding in dealing with slums that must be driven by a strong vision, not just a pragmatic movement to solve problems. Commitment is a strong effort to implement collaboration of the actors so as to be able to remove obstacles that often appear due to differences in the characteristics and interests of the actors. The government of Palangka Raya city is committed to succeeding this KOTAKU Program. Because according to the Mayor of the KOTAKU program intertwined with the vision and mission of the City, namely the realization of the City of Palangka Raya that is 'Advanced, Peaceful and Prosperous City for all'. He told also this program is very supportive of his mission to transform the city of Palangka Raya into Smart City.

\section{Capacity for Joint Action}

The main purpose of collaboration is to produce the benefits that are shared together. Collaboration engages in joint activities to improve the quality of capacity in achieving shared goals. The capacity for joint action is the third aspect of collaborative dynamics that results from principled engagement and shared motivation. Its consist of elements, such as procedural and institutional arrangements, leadership, knowledge, and resources.

Capacity in the form of rules, procedures and technical guidelines is very important as a formal legal basis for implementing the KOTAKU program. At the national level there 
is Law Number (No). 1 of 2011 concerning the implementation of slums must be carried out by the central, regional government and everyone., and also Circular Letter Directorate General of Human Settlements (No). 40 /SE/DC/2016 concerning General Guidelines for KOTAKU.

While at the city level two strategic decisions have been issued which form the basis of KOTAKU, i.e : Mayor Decree of Palangka Raya No. 188.45/130/2016 on; and Mayor Decree of Palangka Raya No. 1888.45/84/2019 concerning the formation of a Working Group on Housing, Settlements, Water Supply and Sanitation (POKJA PPAS).

The leader's capacity in the KOTAKU collaboration program is the City Government of Palangka Raya as the leading sector led directly by the Mayor. Private sector represented by Head of Branch Bank BTN Palangka Raya City. Then the Team Leader from Regional Management Consultant (KMW). There are city level program facilitators led by the city coordinator, and the last one leader of Community Self-help Organization (BKM) in each of urban villages Palangka Raya city.

Knowledge in this context is the clarity of information understood by the actor. Information for the actors has been mostly well distributed through a series of activities to mobilize shared principles in the form of workshops, community consultation and discussion, and informally through Whatsapp coordination groups. The activity becomes an arena for the actors to share the results of their respective activities.

Resources can be interpreted as; financial funding, time and role distribution, technical and administrative support for the implementation of activities, intensity of assistance, etc. For funding this program through World Bank, Islamic Development Bank (IDB), Asian Infrastructure Investment Bank (AIIB), State budget (APBN), Local government budget (APBD), Special Allocation Fund (DAK), CSR and self-help.

While resources in the form of technical support for quality control and program implementation in the field by the Regional Management Consultant (KMW), Expert team, city coordinator and urban village facilitator.

\section{Collaborative Action, Outcomes and Adoption of KOTAKU}

Action is a core of the whole collaboration process. Researchers took samples of two locations in the Menteng Village that have implemented a progressive collaborative 
program through improved drainage and road improvement of residential neighborhoods and improvement in settlement quality. spending a budget to make vertical garden, plants and pots and road coloring with 3D motifs.

Private actor through Bank BTN collaborated with the assistance of six units of garbage carts and six units of vertical garden. Bank BTN also cooperates with various partners from housing developers in Palangka Raya to channel their CSR. The community voluntarily donated money to buy paint.

At the second place, Through investment aid (BDI) the government becomes a leading actor in collaboration with other actors to improve and improve the quality of environmental drainage. At this location the level of community participation was high, even after the physical construction was completed the community took the initiative to carry out household-based vegetable cultivation. Cultivation is done with high creativity using the front yard of the house. The community has also turned slums into fish ponds. These vegetable and fish products are used for the daily needs of the community, so they can reduce household expenses. This activity is fully supported by the City Government through the provision of fish and vegetable seeds.

Pahandut urban village, Palangka Raya City has the largest slum area, which is 39.48 hectares. Now, after intervention from the KOTAKU program, the remaining slum area has become 9.48 hectares. This is a challenge for the government to achieve zero slum in this urban village.

Collaborative action in Pahandut urban village took the object of study in the Murjani area. Based on the settlement plan in this area the slum management approach is through a program that focuses on improving the environment and sanitation. Buildings along the Murjani area on average still use semi-permanent buildings and stage construction. That is due to the condition of the land which is mostly located on the edge of the main river in the City, namely the Kahayan River. So the characteristics of the area are slums with poor sanitation.

The actor involved in the Murjani area is the government by carrying out environmental road improvement. The government also collaborated with nongovernmental groups to build public hydrants and communal septic tanks. While private 
actors, BANK BTN contributed to the procurement of garbage carts. Because of community habits that still throw garbage into the river.

Based on the overview of the collaborative actions above, the results are variant. Collaborative action through road improvement, environmental drainage in the Menteng urban village gives a positive effect on the community so that it makes it easy for them to improve the quality of settlements. While in Pahandut urban village, collaborative actions also benefit. However, the challenge of handling slums in the urban village of Pahandut has its own dynamics. The socioeconomic and cultural characteristics of the people are important factors.

Some of the impacts generated by the collaborative action received feedback from the community. community adaptation to the benefits of collaborative action in menteng is considered good. This can be seen from each of the actors involved who remain at a high level of trust. At the community level, there is also a strong commitment to care for and utilize development. While in the village of Pahandut community adaptation to the impact of collaboration is still low. This is evidenced by the habit of the community to throw garbage in any place is still high. The results of collaborative actions in the form of procurement of carts and landfills have not been used optimally by the community.

\section{Influencing Factors in the collaboration of KOTAKU Political Dynamics and Power Relation}

The dynamics of national politics related to Palangka Raya as one of the main candidates for the new capital candidate. This greatly influences the implementation of the KOTAKU program.

The dynamics of the collaborative process between actors becomes very impressive. The publication of environmental improvement activities is more intense. There is a collective effort for stakeholders in Palangkaraya to present the best side of the city which aims to show the central government that Palangkaraya is worthy of being the new capital.

There is an interesting right from the point of view of power relations that the pattern of informal relations outside the power structure between the Governor and the Mayor provides a 'strong will' for the success of the program. Their relationship formed a collaborative energy that strengthened their role as 'Captain' in the success of the KOTAKU. 


\section{Initiating Leadership}

The Mayor of Palangka Raya as the 'Captain' in the KOTAKU program. He became the initiator in every program related activity. This program is a priority because it is very supportive for the achievement of his political promises, that is realizing Palangka Raya City into a Triple Smart: Smart Environment, Smart society and Smart Economy. He also interacts actively on social media which not only publicizes activities, but also encourages all actors to get involved in the KOTAKU program.

\section{Socioeconomic and Culture Characteristic}

Socio-economic and cultural characteristics influence CGR performance in Palangka Raya City. Collaborative action cross-actors in the Menteng urban village is relatively good because the population structure here tends to be at the middle and upper income levels. Whereas in the Pahandut Village even though collaboration has been going on, the aspects of community outcome and adoption are still low. This is caused by high levels of poverty and low levels of public health so that access to maintenance and utilization of collaboration results is low.

\section{Conclusion}

Based on key indicators of program achievements, the performance implementation of KOTAKU in Palangka Raya City was successful. This can be seen from the total slum area which has been reduced significantly.

The dynamics of collaboration show that the interactive cycle between principle engagement, shared motivation and capacity for joint action is going well. Principle engagement is formally established through workshops and deliberations. Then informally principled engagement is also formed through interactions in the whatsapp coordination group.

On the dynamics of shared motivation All actors involved show egalitarian attitudes. Although each actor has a different purpose of interest, but the trust and understanding between one actor with another is well established. This factor is driving a strong commitment to jointly succeed the KOTAKU program. Each actor has a strong capacity to 
carry out collaborative actions. Government actors compile procedural legal basis through decree.

Leadership of all actors involved plays an important role so that knowledge in the form of information thanks to collaborative action is well distributed. This is supported by well-managed human and financial resources.

The intervention of the KOTAKU program in Menteng urban village shows the phenomenon of collaborative action in the form of active participation of government, private and community actors in improving the quality of environmental roads by creating vertical garden and beautifying roads with three dimensions (3D) painting. Collaborative action also changes the dirty drainage as a fish pond. In addition, the community also cultivates vegetable plants using their own frontyard. These fish and vegetable farming activities open access to enhancing community economic capacity.

Collaboration in Pahandut urban village is less than optimal because it is influenced by the social, economic and cultural characteristics of the community so that community adoption of collaborative actions and results is have not optimal. This can be seen in the community's habit of still throwing garbage into the river, even though the collaboration between the actors has provided a cart and a garbage dump.

From the CGR perspective, there are two factors that have a positive influence on the implementation of the KOTAKU program, i.e : political dynamic or power relation and initiating leadership. While social, economic and cultural characteristic tend to hamper program implementation. The recommendation in the future is that collaborative action must be expanded again by collaborating with CSR forums as a source of funding and universities as a source of knowledge.

\section{References}

Agranoff, R., \& McGuire, M. (2003). Collaborative public management: New strategies for local governments. Washington, DC: Georgetown Univ. Press.

Alzamil, W. S. (2018). Evaluating Urban Status of Informal Settlements in Indonesia: A Comparative Analysis of Three Case Studies in North Jakarta. Journal of Sustainable Development, 11(4), 148. https://doi.org/10.5539/jsd.v11n4p148 
Ansell, C., \& Gash, A. (2007). Collaborative Governance in Theory and Practice. Journal of Public Administration Research and Theory, 18(4), 543-571. https://doi.org/10.1093/jopart/mum032

Barber, B. R. (2013). If mayors ruled the world: Dysfunctional nations, rising cities. New Haven: Yale University Press.

Bathari, A. M., Solo Limba, R., \& Mustafa, L. O. (2018). Implementation of the KOTAKU Program: Case Study in Kendari. Journal Publicuho, 1(2), 37. https://doi.org/10.35817/jpu.v1i2.5827

Corburn, J., \& Sverdlik, A. (2017). Slum Upgrading and Health Equity. International Journal of Environmental Research and Public Health, 14(4), 342. https://doi.org/10.3390/ijerph14040342

Donahue, J. D., Zeckhauser, R., \& Breyer, S. (2011). Collaborative governance: Private roles for public goals in turbulent times. Princeton: Princeton University Press.

Emerson, K., Nabatchi, T., \& Balogh, S. (2012). An Integrative Framework for Collaborative Governance. Journal of Public Administration Research and Theory, 22(1), 1-29. https://doi.org/10.1093/jopart/mur011

Emerson, Kirk, \& Nabatchi, T. (2015). Evaluating the Productivity of Collaborative Governance Regimes: A Performance Matrix. Public Performance \& Management Review, 38(4), 717-747. https://doi.org/10.1080/15309576.2015.1031016

Florini, A., \& Pauli, M. (2018). Collaborative governance for the Sustainable Development Goals. Asia \& the Pacific Policy Studies, 5(3), 583-598. https://doi.org/10.1002/app5.252

Keping, Y. (2018). Governance and Good Governance: A New Framework for Political Analysis. Fudan Journal of the Humanities and Social Sciences, 11(1), 1-8. https://doi.org/10.1007/s40647-017-0197-4

Koski, C., Siddiki, S., Sadiq, A.-A., \& Carboni, J. (2018). Representation in Collaborative Governance: A Case Study of a Food Policy Council. The American Review of Public Administration, 48(4), 359-373. https://doi.org/10.1177/0275074016678683

Lahat, L., \& Sher-Hadar, N. (2019). A threefold perspective: Conditions for collaborative governance. Journal of Management and Governance. https://doi.org/10.1007/s10997019-09465-1 
Mah, D. N., \& Hills, P. (2012). Collaborative governance for sustainable development: Wind resource assessment in Xinjiang and Guangdong Provinces, China. Sustainable Development, 20(2), 85-97. https://doi.org/10.1002/sd.466

Margerum, R. D. (2011). Beyond Consensus: Improving Collaborative Planning and Management. Cambridge: MA: MIT Press.

Morse, R. S., \& Stephens, J. B. (2012). Teaching Collaborative Governance: Phases, Competencies, and Case-Based Learning. Journal of Public Affairs Education, 18(3), 565-583. https://doi.org/10.1080/15236803.2012.12001700

Neo, B. S., \& Chen, G. (2007). Dynamic governance: Embedding culture, capabilities and change in Singapore. New Jersey: World Scientific.

Noh, A., \& Yashaiya, N. H. (2018). Administrative Reform in Malaysia: Experimenting with Collaborative Governance. In A. Farazmand (Ed.), Global Encyclopedia of Public Administration, Public Policy, and Governance (pp. 1-8). https://doi.org/10.1007/978-3319-31816-5_3510-1

O'Flynn, J., \& Wanna, J. (2008). Collaborative Governance: A new era of public policy in Australia? https://doi.org/10.26530/OAPEN_458884

O'Leary, R., \& Vij, N. (2012). Collaborative Public Management: Where Have We Been and Where Are We Going? The American Review of Public Administration, 42(5), 507-522. https://doi.org/10.1177/0275074012445780

Sabaruddin, A. S., \& Said, A. L. (2018). Collaborative Governance In Household Handling. International Journal of Scientific Research and Management, 6(11). https://doi.org/10.18535/ijsrm/v6i11.sh03

Sinthia, S. A. (2013). Sustainable Urban Development of Slum Prone Area of Dhaka City. 7(3), 8.

Thomson, A. M., \& Perry, J. L. (2006). Collaboration Processes: Inside the Black Box. Public Administration Review, 66(s1), 20-32. https://doi.org/10.1111/j.1540-6210.2006.00663.x

Yusnadi, Y., Lubis, L., \& Nuraflah, C. A. (2019). Model of Communication Policy on the Development of the City without Slum (KOTAKU) Medan City. Budapest International Research and Critics Institute (BIRCI-Journal) : Humanities and Social Sciences, 2(2), 284-292. https://doi.org/10.33258/birci.v2i2.261 
Zhou, Z. (2014). Towards collaborative approach? Investigating the regeneration of urban village in Guangzhou, China. Habitat International, 44, 297-305. https://doi.org/10.1016/j.habitatint.2014.07.011 